\title{
Plaque assay for human coronavirus NL63 using human colon carcinoma cells
} Petra Herzog1,3, Christian Drosten*2 and Marcel A Müller²

\begin{abstract}
Address: ${ }^{1}$ Bernhard Nocht Institute for Tropical Medicine, Bernhard-Nocht-Str. 74, D-20359 Hamburg, Germany, ${ }^{2}$ Institute of Virology, University of Bonn Medical Centre, Sigmund-Freud-Str. 25, 53127 Bonn, Germany and ${ }^{3}$ Qiagen Hamburg GmbH, Königstr. 4a, D-22767 Hamburg, Germany

Email: Petra Herzog - herzog@bni-hamburg.de; Christian Drosten* - drosten@virology-bonn.de; Marcel A Müller - muller@virology-bonn.de

* Corresponding author
\end{abstract}

Published: 12 November 2008

Virology Journal 2008, 5:138 doi:10.1186/1743-422X-5-138

This article is available from: http://www.virologyj.com/content/5/I//38

(C) 2008 Herzog et al; licensee BioMed Central Ltd.

This is an Open Access article distributed under the terms of the Creative Commons Attribution License (http://creativecommons.org/licenses/by/2.0), which permits unrestricted use, distribution, and reproduction in any medium, provided the original work is properly cited.
Received: 22 October 2008

Accepted: 12 November 2008

\begin{abstract}
Background: Coronaviruses cause a broad range of diseases in animals and humans. Human coronavirus (hCoV) NL63 is associated with up to $10 \%$ of common colds. Viral plaque assays enable the characterization of virus infectivity and allow for purifying virus stock solutions. They are essential for drug screening. Hitherto used cell cultures for hCoV-NL63 show low levels of virus replication and weak and diffuse cytopathogenic effects. It has not yet been possible to establish practicable plaque assays for this important human pathogen.
\end{abstract}

Results: 12 different cell cultures were tested for susceptibility to hCoV-NL63 infection. Human colon carcinoma cells $(\mathrm{CaCo}-2)$ replicated virus more than 100 fold more efficiently than commonly used African green monkey kidney cells (LLC-MK2). CaCo-2 cells showed cytopathogenic effects 4 days post infection. Avicel, agarose and carboxymethyl-cellulose overlays proved suitable for plaque assays. Best results were achieved with Avicel, which produced large and clear plaques from the $4^{\text {th }}$ day of infection. The utility of plaque assays with agrose overlay was demonstrated for purifying virus, thereby increasing viral infectivity by $1 \log 10 \mathrm{PFU} / \mathrm{mL}$.

Conclusion: CaCo-2 cells support hCoV-NL63 better than LLC-MK2 cells and enable cytopathogenic plaque assays. Avicel overlay is favourable for plaque quantification, and agarose overlay is preferred for plaque purification. HCoV-NL63 virus stock of increased infectivity will be beneficial in antiviral screening, animal modelling of disease, and other experimental tasks.

\section{Background}

Coronaviruses are large enveloped plus-strand RNA viruses that are currently classified in three groups or presumptive genera [1-3]. Group 1 is further divided into two phylogenetic clades exemplified by the transmissible gastroenteritis virus (TGEV) and the porcine epidemic diarrhoea virus (PEDV), respectively. The latter clade contains two prototypic human coronaviruses (hCoV), termed hCoV-229E and -NL63 [4,5]. Like group 1, group 2 contains mammalian CoV. These include two human patho- genic prototypes, termed hCoV-OC43 and -HKU1, several important animal pathogens such as the bovine $\mathrm{CoV}$ and the murine hepatitis virus, as well as the SARS-CoV [6-8]. Group 3 contains foremostly avian $\mathrm{CoV}$ [9].

HCoV-229E and OC43 as well as the more recently identified hCoV-HKU1 and - NL63 are major causes of common colds in wintertime [10]. HCoV-NL63 was isolated in African green monkey kidney cells (LLC-MK2) from a seven month old infant with bronchiolitis and conjuncti- 
vitis [4]. In further investigations the virus was predominantly detected in children with respiratory infections [11-14]. Up to $10 \%$ of children with respiratory disease yielded hCoV-NL63 [10,11,15-17].

Because of its relatively high prevalence hCoV-NL63 could become an important model in screening for anti-coronaviral agents $[12,18]$. Several studies have suggested, e.g., that $\mathrm{hCoV}$ protease inhibitors would be cross-reactive among different hCoV [19-21]. Antiviral screening relies on the detection of replicating virus in cell culture. For this and other experimental tasks, plaque assays have proven to be simple in application and efficacious in representing virus viability.

Plaque assays make use of viscous overlays to cover cells immediately after infection, thus limiting virus spread and restricting virus growth to foci of cells at the sites of initial infection. If virus contributes no or low cytopathic effects to cells, these foci may be visualized by immunostaining $[22,23]$. If virus induces strong cytopathogenic effects (CPE), cells in plaques are lysed and plaques can be visualized by staining of the residual intact cells. Cytopathogenic plaque assays are compatible with high throughput screening $[24,25]$ and facilitate plaque purification and cloning of virus. This in turn is helpful in obtaining virus stocks of optimized infectivity, e.g., by decreasing the amount of defective interfering (di) particles that accumulate during serial passaging of $\mathrm{CoV}$ [26].

Important technical achievements have been made in studying NL63 replication, including, most recently, the development of an infectious cDNA clone [27]. Still it is a major obstacle that hCoV-NL63 replicates slowly and at relatively low titres in all current cell cultures, such as LLCMK2 and Vero-B4 cells $[4,28,29]$. Because the virus contributes very weak and diffuse CPE to these cells, there is no cytopathic plaque assay available for non-recombinant virus [28].

Although hCoV-NL63 seems to replicate in the upper and lower airways, there are many $\mathrm{CoV}$ that predominantly infect the enteric tract, such as TGEV, PEDV, the feline enteric $\mathrm{CoV}$, and the bovine coronavirus [30,31]. SARS$\mathrm{CoV}$ was detected in faecal swabs from SARS patients [32]. SARS-CoV was shown to replicate in colon carcinoma cells (CaCo-2) [33] that are routinely used for growing entero- and adeno-, and astroviruses [34]. Interestingly, SARS-CoV and hCoV-NL63 were shown to use the same receptor for virus entry, the angiotensin converting enzyme 2 (ACE2) [35].

We show here that CaCo-2 cells are highly susceptible for hCoV-NL63 infections and that virus propagation in these cells is much more efficient than in LLC-MK2 cells. By testing different overlays and assay formats we developed cytopathogenic NL63 plaque assays that can be used for analytical and preparative purposes.

\section{Results and discussion Susceptibility of different cell lines to hCoV-NL63 and cytopathogenic effects}

LLC-MK2 and Vero cells do not cause clear CPE on infection with hCoV-NL63. Because this virus uses the same receptor as the SARS-CoV, 12 different cell cultures susceptible to SARS-CoV infection were tested for susceptibility to hCoV-NL63 $[34,36,37]$ (Table 1). Cells in six-well plates were infected with $10 \mathrm{e} 4$ plaque-forming units of

Table I: Comparison of hCoV-NL63 replication by real time RT-PCR using different cell cultures

\begin{tabular}{lllll}
\hline Designation* & Day 0 [copies/ $\boldsymbol{L} \mathbf{L}]$ & Day $\mathbf{7}$ [copies/ $\boldsymbol{\mu L}$ ] & Amplification factor & Cytopathogenic effect (CPE) \\
\hline Vero E6 & $6.94 \mathrm{e} 3$ & $3.05 \mathrm{e} 7$ & $4.39 \mathrm{e} 3$ & None \\
Vero FM & $1.78 \mathrm{e} 4$ & $4.51 \mathrm{e} 9$ & $2.54 \mathrm{e} 5$ & None \\
CaCo-2 & $3.55 \mathrm{e} 3$ & $1.25 \mathrm{e} 10$ & $3.54 \mathrm{e} 6$ & round and detached, dead cells with cell debris in \\
& & & & supernatant, strong effect \\
Calul & $2.61 \mathrm{e} 4$ & $5.33 \mathrm{e} 6$ & $2.04 \mathrm{e} 2$ & None \\
Calu6 & $7.95 \mathrm{e} 3$ & $5.00 \mathrm{e} 5$ & $6.29 \mathrm{el}$ & None \\
POEK & $8.11 \mathrm{e} 4$ & $3.03 \mathrm{e} 5$ & $3.74 \mathrm{e} 0$ & None \\
PKI3 & $2.66 \mathrm{e} 2$ & $7.78 \mathrm{e} 5$ & $2.93 \mathrm{e} 3$ & None \\
$2931 \mathrm{P}$ & $3.67 \mathrm{e} 3$ & $3.09 \mathrm{e} 7$ & $8.42 \mathrm{e} 3$ & None \\
FeA & $1.45 \mathrm{e} 4$ & $5.83 \mathrm{e} 5$ & $4.03 \mathrm{el}$ & None \\
RD & $3.14 \mathrm{e} 5$ & $1.57 \mathrm{e} 4$ & $4.99 \mathrm{e}-2$ & None \\
PS & $1.20 \mathrm{e} 4$ & $1.44 \mathrm{e} 6$ & $1.19 \mathrm{e} 2$ & round and detached, weak effect \\
LLC-MK2 & $4.00 \mathrm{e} 3$ & $2.65 \mathrm{e} 6$ & $6.62 \mathrm{e} 2$ & \\
\end{tabular}

* Vero E6 rhesus kidney cells (ATCC CRL-1586), Vero FM rhesus kidney cells (ATCC CCL-8I), CaCo-2 human colon carcinoma (ATCC HTB-37), Calu I human lung carcinoma (ICLC HTL95002), Calu 6 human lung carcinoma (ICLC HTL97003), POEK porcine foetal kidney (cell culture collection of the Robert Koch-Institute (RKI), Berlin, Germany), PKI3 porcine kidney (cell culture collection of the Bernhard-Nocht-Institute (BNI), Hamburg, Germany), 293 human embryonic kidney (ATCC CRL-1573), FEA feline embryonic fibroblast (kindly provided by Dr. Marcel Asper, NewLab Inc., Cologne), RD human rhabdomyosarcoma cells (RKI), PS porcine kidney cells (RKI), and LLC-MK2 African green monkey kidney cells (ATTC CCL-7, kindly provided by Lia van der Hoek, Academic Medical Center Amsterdam, The Netherlands). 
hCoV-NL63 virus stock LLC-MK2 NP. RNA concentrations in supernatants were measured short after virus adsorption (i.e., in fresh medium after washing off of the infection supernatant), and 7 days later (Table 1). Increase of virus RNA was less than 1000-fold in seven of 12 cultures. Interestingly, this included LLC-MK2, the prototype cell culture for NL63. In spite of a low amplification factor these cells showed the usual weak CPE that is typically observed when infected with hCoV-NL63.

Vero cells seemed to support virus growth efficiently but produced no CPE. Interestingly, there was a remarkable difference between Vero E6 and Vero FM cells (Table 1). In our hands these cells also showed differences in growth of SARS-CoV. Vero FM consistently showed more pronounced CPE than Vero E6 but there were no significant differences in RNA amplification (not shown).

CaCo-2 cells amplified virus RNA most efficiently, and showed a clearly visible CPE starting from day 4 after infection. Cells became rounded, detached from the surface, and showed morphological signs of cell death (Figure 1).

For confirmation of differential replication efficiencies, CaCo-2 and LLC-MK2 cells were infected in parallel. Both cell lines were seeded in $25 \mathrm{~cm}^{2}$ flasks, and infected at multiplicities of infection of 0.005. Samples of supernatants were taken daily from day 0 to 7 and analyzed by real time RT-PCR. As shown in Figure 2, CaCo-2 cells replicated virus more efficiently than LLC-MK2. From day 3

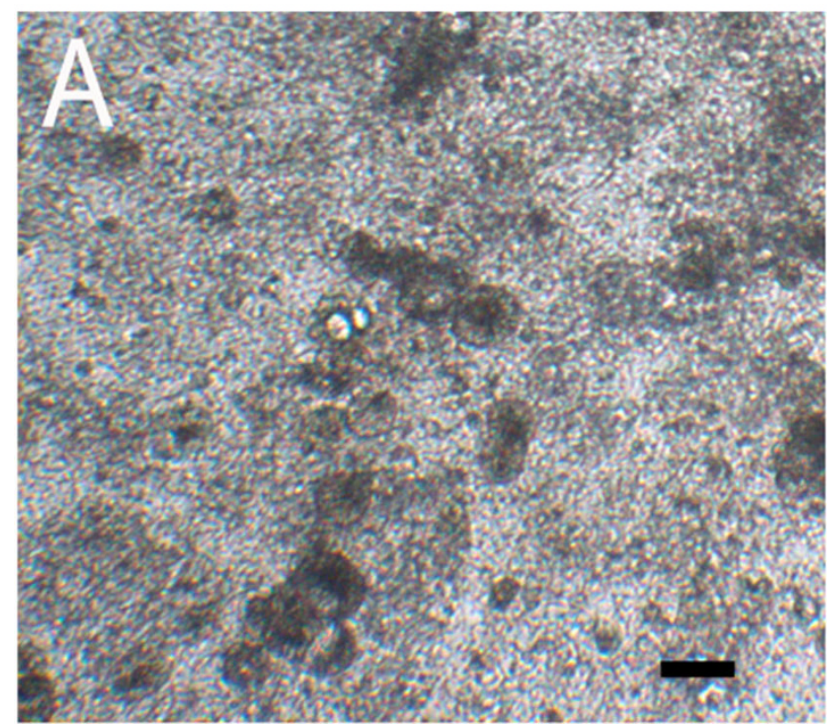

onward, RNA concentrations were more than 100 fold higher in CaCo- 2 cells. Because of the clear CPE observed in CaCo-2 cells, these cells were tested for their utility in a cytopathogenic plaque assay.

\section{Comparison of different overlays}

Three overlay techniques commonly used for plaque assays were tested for their suitability [23]. CaCo-2 cells were infected in 6-well plates with hCoV-NL63. After one hour, supernatants were removed, cells washed with PBS, and overlaid as follows.

For CMC overlays, $1 \mathrm{~mL}$ fresh DMEM was added to each well. Subsequently $1 \mathrm{~mL}$ of $1.6 \% \mathrm{CMC}$ solution was slowly added per well. Agarose overlays (1\% final concentration) were prepared by melting $2 \%$ agarose at $70^{\circ} \mathrm{C}$, cooling it in a water bath to $42^{\circ} \mathrm{C}$, and mixing it immediately before application with an equal volume of $2 \times$ DMEM stored at room temperature. Two $\mathrm{mL}$ of the mixture were carefully applied to each well. Avicel overlays were made by mixing $2.4 \%$ Avicel solution with an equal volume of $2 \times$ DMEM. $2 \mathrm{~mL}$ of the mixture were immediately added to each well.

Plaque assays were incubated without disturbing at $37^{\circ} \mathrm{C}$ and $5 \% \mathrm{CO}_{2}$. Overlays were removed on day five and cells were fixed with a solution of $4 \%$ formaldehyde in PBS. After 30 min the formaldehyde solution was removed, cells were washed twice with PBS, and stained with a $0.2 \%$ crystal violet solution. As shown in Figure 3, plaques were

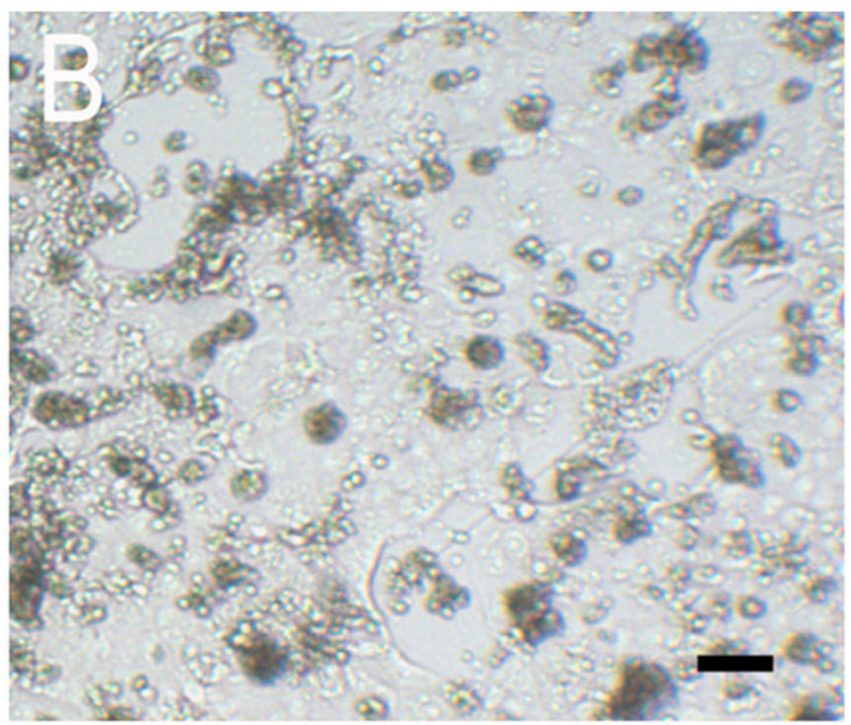

Figure I

Cytopathogenic effect of hCoV-NL63 on human colon carcinoma cells (CaCo-2). CaCo-2 cells 5 days after infection with hCoV-NL63 at an multiplicity of infection of 0.1 (agarose overlay technique). A, mock-infection; B, infection. Photographs were taken at 40 -fold magnification; bars represent $20 \mu \mathrm{m}$. 


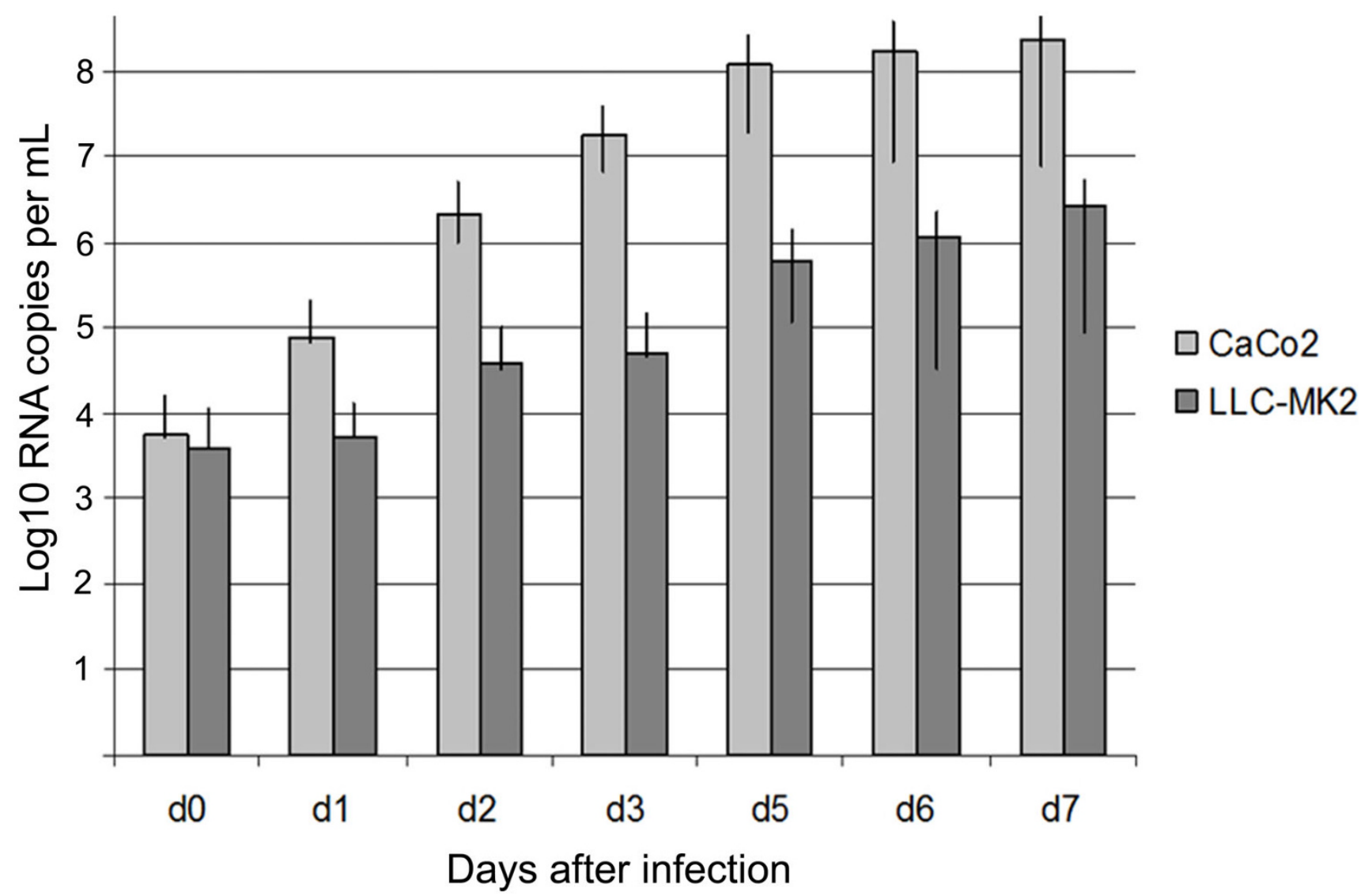

Figure 2

Growth kinetics of hCoV-NL63 on LLC-MK2 and CaCo-2 cells. $25 \mathrm{~cm}^{2}$ flasks of LLC-MK2 or CaCo-2 cells were infected at multiplicities of infection of 0.005 for I h, washed twice with PBS, and subsequently supplied with $10 \mathrm{~mL}$ DMEM. Samples were taken daily from day 0 to 7 (except day 4) and analyzed by real time RT-PCR. Error bars indicate ranges of three independent experiments.

visible with all three overlays, but staining was clearest with Avicel.

\section{Incubation times}

HCoV-NL63 culture with LLC-MK2 cells takes more than 7 days until first signs of weak CPE become visible. In order to test whether incubation times could be reduced with CaCo- 2 cells, five plaque assays on virus dilution series were done with Avicel overlays and terminated by fixation after $1,2,3,4$, and 5 days, respectively. On days 1 and 2, no plaques were visible (not shown). Termination at day 3 yielded plaques only at high virus concentration (Figure 4). From day 4 onward, plaques were visible in the lowest detectable virus concentration. Plaques on day 5 were larger, but did not increase in number.

\section{Plaque preparation}

Work with hCoV-NL63 is complicated by low infectious titers in virus stock solutions. In order to obtain more infectious virus solutions, our standard virus stock LLCMK2 NP (see Materials and Methods section) was plaquepurified using the agarose overlay. Because life staining of cells with neutral red solution was not successful on CaCo-2 cells (not shown), we used an alternative technique of plaque preparation.

Limiting dilution infections were done on 6-well plates. After 5 days, cytopathic foci were identified by scanning through the wells with an inverted microscope at low magnification, lighting through the clear agarose overlay. The positions of CPE foci were marked with a permanent marker (it was helpful to turn up the microscope light for this). The agarose overlay was penetrated with a pipette and 10 to $20 \mu \mathrm{l}$ of fluid was aspirated underneath the overlay. This fluid was resuspended in $100 \mu \mathrm{l}$ of Opti Pro serum-free medium, which served as the starting solution for a new limiting dilution infection series in the next 6well plate plaque assay. Three rounds of purification were 


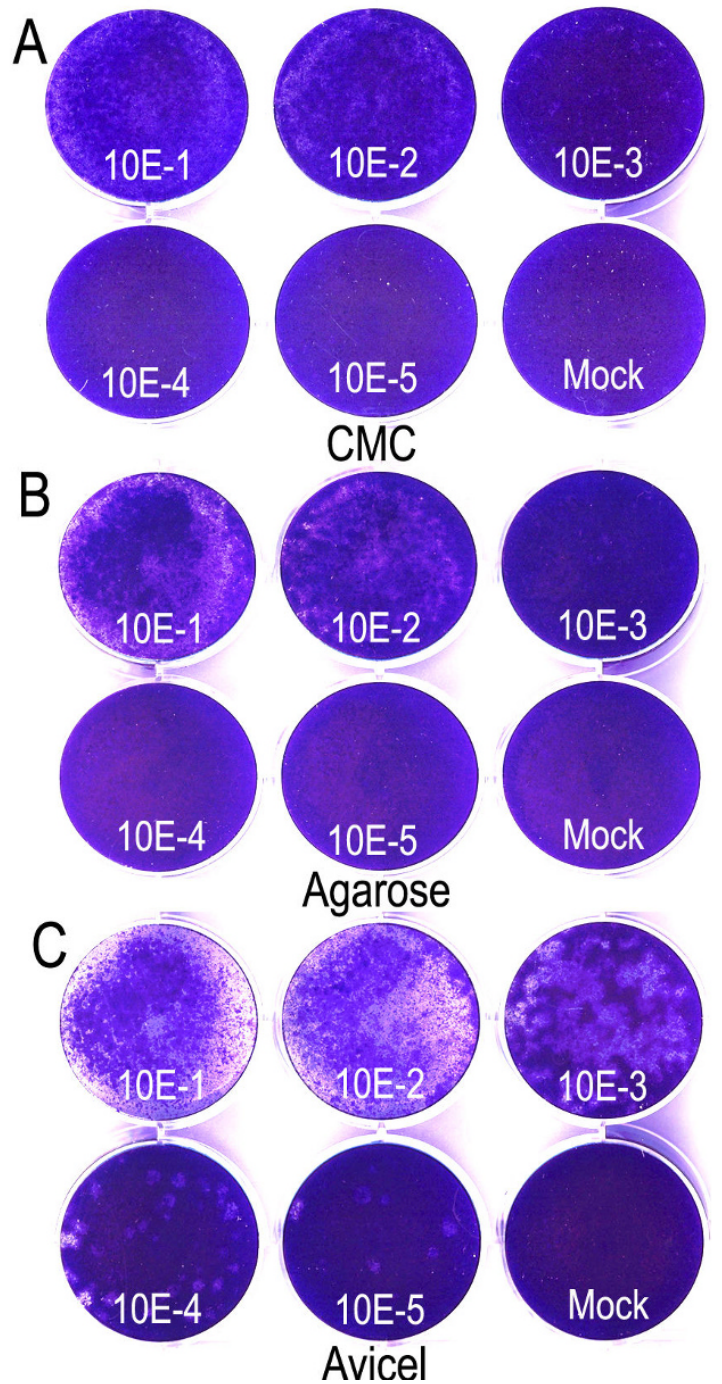

Figure 3

Plaque assay for hCoV-NL63 on CaCo-2 cells using different overlays. HCoV-NL63 was serially diluted on $\mathrm{CaCo}-2$ cells (IOe-I until IOe-5). After I h of virus adsorbtion different overlays were added. After 5 days cells were fixed with $4 \%$ formaldehyde and stained with $0.2 \%$ crystal violet solution. A) carboxymethyl-cellulose; B) agarose; C) Avicel.

done. After the last round, aspirated fluid was inoculated in $5 \mathrm{~mL}$ of Opti Pro serum-free medium, which was then overlaid on confluent CaCo-2 cells in a $25 \mathrm{~cm}^{2}$ flask for infection. After infection for one hour and washing, $5 \mathrm{~mL}$ DMEM were added and flasks were incubated at $37^{\circ} \mathrm{C}$, $5 \% \mathrm{CO}_{2}$ for four days. Stocks were harvested and stored as described for the original LLC-MK2 stock in the Materials and Methods section. The purified virus is hereafter referred to as CaCo-2 PP (for plaque-purified).
To compare the infectivity of the plaque-purified virus with the original LLC-MK2 virus stock (see Materials and Methods section), viral titres were determined by Avicel plaque assay as shown in Figure 5. CaCo-2 PP was about 10-fold more infectious than LLC-MK2 NP. Plaque assays were repeated three times (not shown). Mean titres were determined to be $1.4 \times 10 \mathrm{e} 6 \mathrm{PFU} / \mathrm{mL}$ and $1.3 \times 10 \mathrm{e} 5 \mathrm{PFU} /$ $\mathrm{mL}$, respectively, for CaCo-2 PP and LLC-MK2 NP. Absolute quantification of virus RNA by real-time RT-PCR yielded $4.8 \times 10 \mathrm{e} 11 \mathrm{RNA}$ copies/mL for CaCo-2 PP and $5.3 \times 10 \mathrm{e} 10$ copies $/ \mathrm{mL}$ for LLC-MK2 NP.

It was interesting to note that both virus stocks had rather high RNA concentrations as opposed to their infectivities. PFU/RNA ratios were $2.92 \times 10 \mathrm{e}-6$ for CaCo- $2 \mathrm{PP}$ and $2.45 \times 10 \mathrm{e}-6$ for LLC-MK2 NP. This high excess of RNA over infectious units might be attributable to the virus harvesting procedure, possibly releasing nonpackaged RNA along with virus particles during freeze-thawing. Because PFU/RNA ratios were very similar for both stocks, it appeared unlikely that elimination of defective interfering particles had contributed the gain of infectivity. It will be interesting in future studies to see whether hCoV-NL63 might have adapted to CaCo-2 cells during plaque purification.

\section{Conclusion}

CaCo-2 cells seem to support hCoV-NL63 replication significantly better than hitherto used culture cells. Their application for a cytopathogenic plaque assay facilitates quantification of infectivity and enables studies using plaque morphology. Short incubation time of 4 days is compatible with high-throughput applications such as drug screening. The use of Avicel as an overlay is favourable for plaque quantification, whereas agarose overlays are preferred for plaque purification. Virus stock of increased infectivity will be beneficial for antiviral screening, animal modelling of disease, and other experimental tasks.

\section{Methods \\ Cell cultures}

All cells were cultivated in DMEM (Dulbecco's Modified Eagles Medium) (PAA, Cölbe, Germany) with 4.5 g/L Glucose (PAA), supplemented with $10 \%$ Foetal Bovine Serum "GOLD" (PAA), 1\% Penicillin/Streptomycin $100 \times$ concentrate (Penicillin $10000 \mathrm{U} / \mathrm{mL}$, Streptomycin $10 \mathrm{mg} /$ $\mathrm{mL}$ ) (PAA), 1\% L-Glutamine $200 \mathrm{mM}, 1 \%$ Sodium Pyruvate $100 \mathrm{mM}$ (PAA), 1\% MEM nonessential amino acids (NEAA) $100 \times$ concentrate $($ PAA). Utilized cell cultures are identified in Table 1. For passaging, cells were detached using trypsin-EDTA (PAA), except CaCo-2 cells. These were routinely subcultured by scraping and pipetting for mechanical re-suspension. 


\section{Day 3}
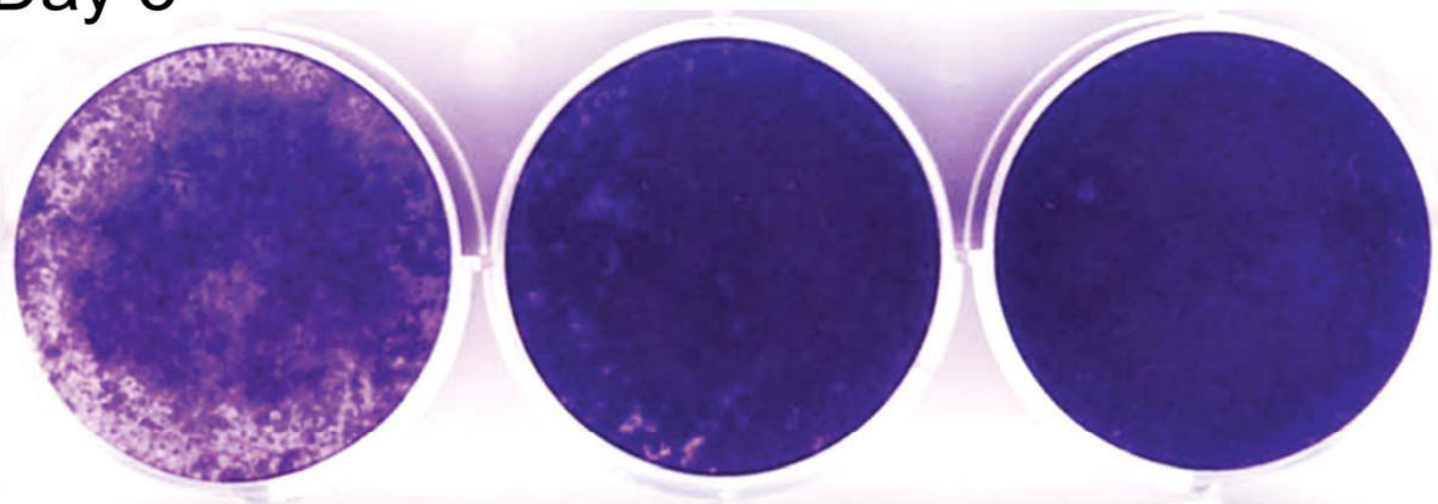

\section{Day 4}
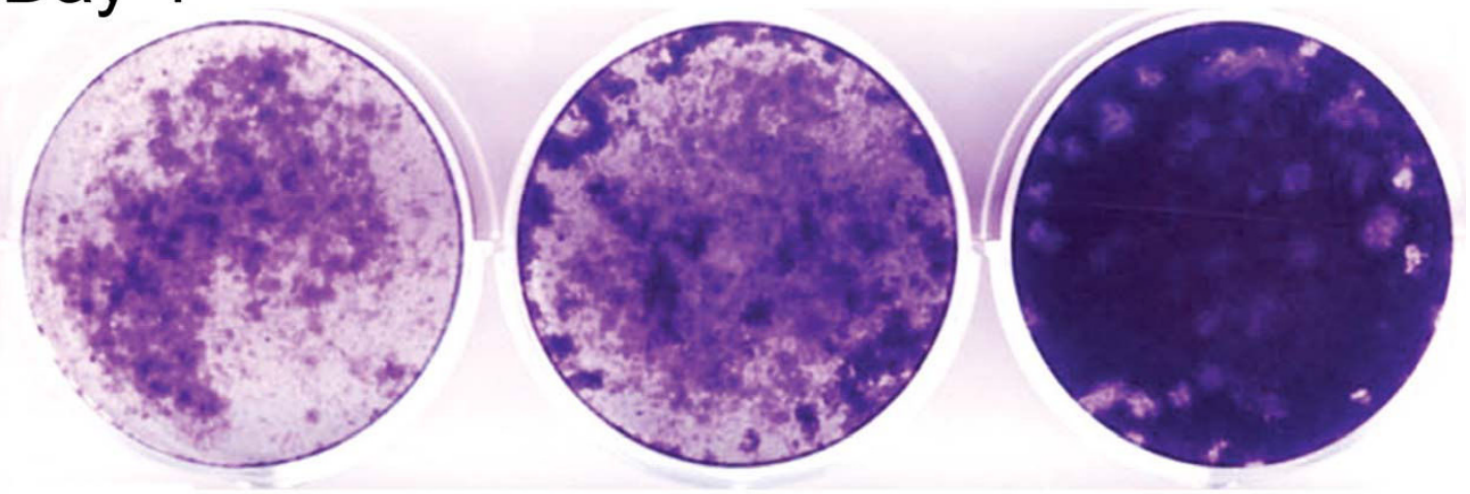

\section{Day 5}

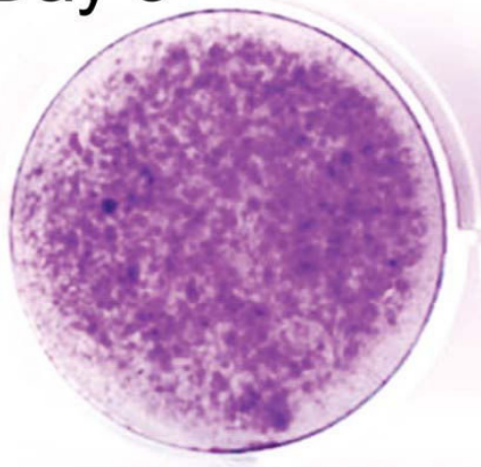

10E-1

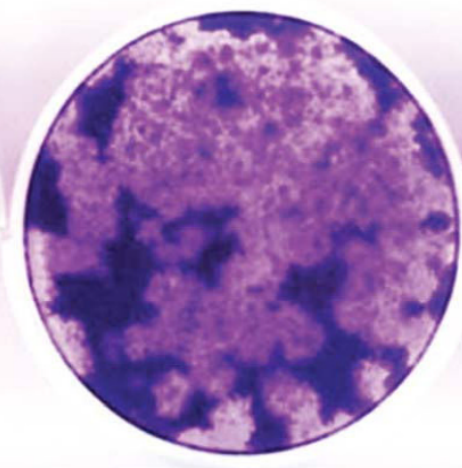

10E-2

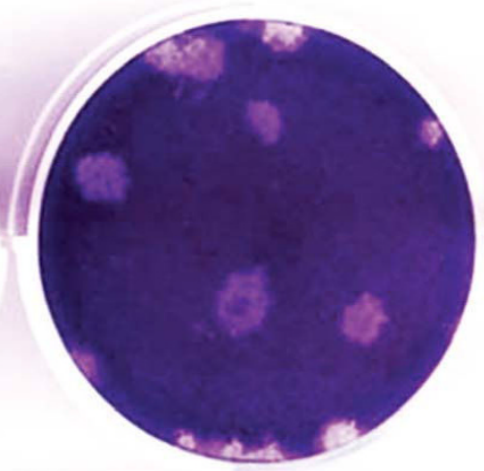

10E-3

Figure 4

Plaque assays with different incubation times. Plaque assays were performed with Avicel overlay and incubated for 3,4 , and 5 days, respectively. The dilution factor of LLC-MK2 NP virus stock used for infection is shown on the bottom. 

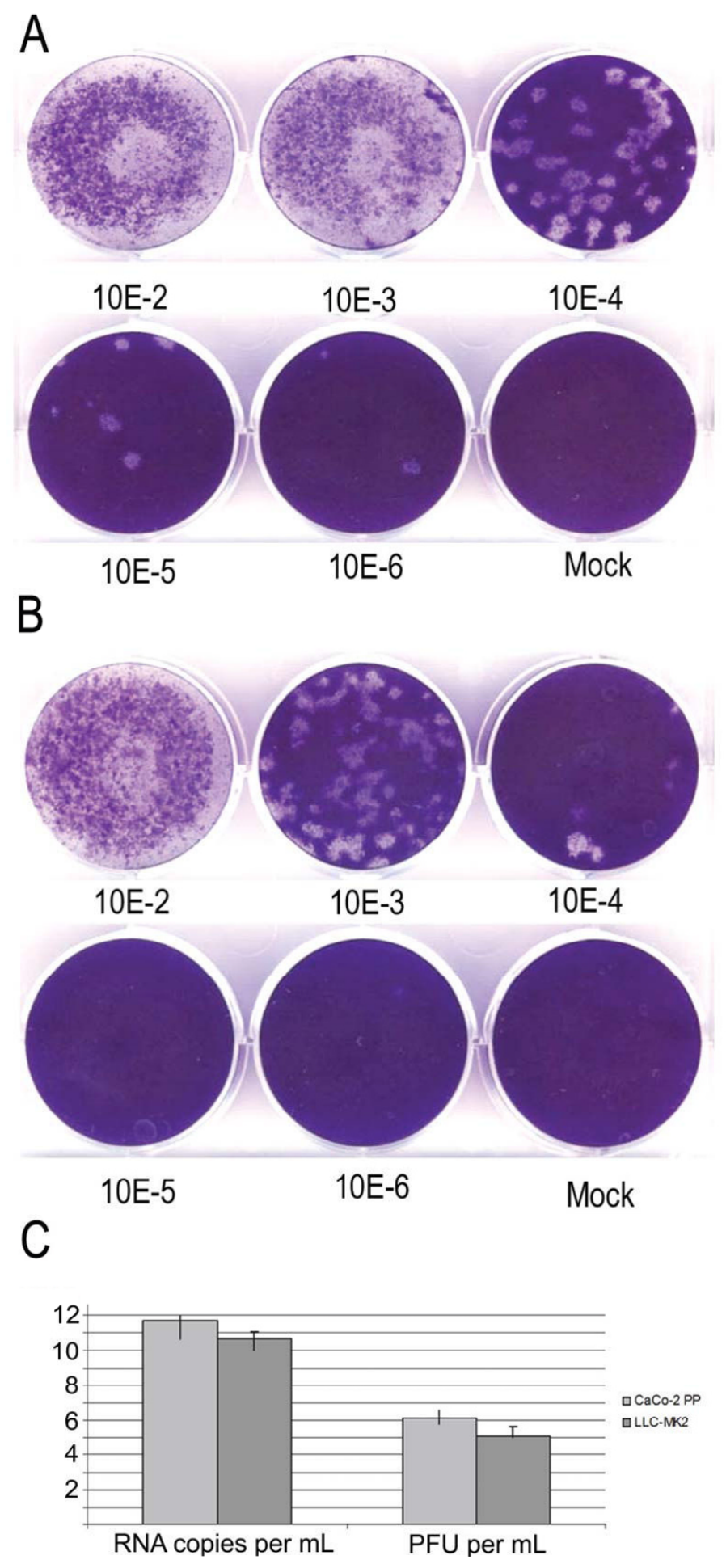

\section{Figure 5}

Effect of plaque purification. A, plaque assay with Avicel overlay on purified virus stock CaCo-2 PP. B, plaque assay on nonpurified virus stock LLC-MK2 NP. C, viral RNA copies per $\mathrm{mL}$ of supernatant (left) and plaque forming units per $\mathrm{mL}$ of supernatant (right) for CaCo-2 PP and LLC-MK2 NP virus stocks (log scale). Error bars show ranges of three independent experiments. 


\section{HCoV-NL63 virus stock solution}

An eighth passage virus stock of hCoV-NL63 was kindly provided by Lia van der Hoek, AMC Amsterdam. It was grown in LLC-MK2 cells in limiting dilution series, recovering it three times from the last well of a dilution series still showing diffuse CPE. Subconfluent LLC-MK2 monolayers were infected in $75 \mathrm{~cm}^{2}$ flasks with virus supernatant from the last round of limiting dilution culture at a ratio of 1:100 $(200 \mu \mathrm{l}$ virus supernatant in $20 \mathrm{~mL}$ of fresh medium). This concentration was the highest virus dilution still infectious in this culture format. The flasks were incubated at $37^{\circ} \mathrm{C}, 5 \% \mathrm{CO}_{2}$, and harvested on day four. For harvesting, flasks were frozen at $-70^{\circ} \mathrm{C}$ and thawed. Cells and supernatant were centrifuged for $10 \mathrm{~min}$ at 5000 $\mathrm{rpm}$. Cleared supernatant was aliquoted and stored at $70^{\circ} \mathrm{C}$. This virus stock is hereafter referred to as LLC-MK2 NP (for non-purified).

\section{Infection of cells}

Cells were seeded in 6 -well plates at approximately $4 \times$ $10 \mathrm{e} 5$ cells per well and incubated until the monolayer was $70-80 \%$ confluent. CaCo-2 cells were grown to $100 \%$ confluence. Prior to infection cells were washed with $1 \times$ phosphate buffered saline (PBS). Virus inoculum in 900 $\mu \mathrm{L}$ GIBCO Opti Pro serum free medium (Invitrogen, Karlsruhe, Germany) plus 1\% Penicillin/Streptomycin (PAA) and 1\% L-Glutamine (PAA) was added to each well. Inoculum was removed after one hour of incubation. Cells were washed twice with $1 \times$ PBS and supplemented with 2 mL DMEM per well.

\section{RNA extraction and real time $R T-P C R$}

Viral RNA was extracted from cell culture supernatant with the QIAamp Viral RNA mini Kit (QIAGEN, Hilden, Germany). Real time RT-PCR for hCoV-NL63 with absolute virus RNA quantification was performed as described previously [38].

\section{Media and overlays for plaque assays}

A $2.4 \%(w / v)$ suspension of Avicel RC-581 (FCM BioPolymer, Brussels, Belgium) was prepared in distilled water and autoclaved $\left(20 \mathrm{~min} 121^{\circ} \mathrm{C}\right)[23]$. A $2 \%(\mathrm{w} / \mathrm{v})$ suspension of agarose (Plaque Agarose, Biozym, Hessisch Oldendorf, Germany) was prepared in distilled water and autoclaved. A 1.6\% carboxymethyl cellulose (CMC) solution was prepared by autoclaving $\mathrm{CMC}$ powder $(\mathrm{BDH}$, Poole, UK) with a magnetic stirrer. Autoclaved powder was hydrated in DMEM at $1.6 \%(\mathrm{w} / \mathrm{v})$ and stirred overnight until homogenous.

Double concentrated Dulbecco's modified Eagle medium (DMEM) was prepared by mixing DMEM (PAA) with 9.48 g/L DMEM Powder (Biochrom, Berlin, Germany), supplemented with 20\% Foetal Bovine Serum "GOLD" (PAA), 2\% Penicillin/Streptomycin $100 \times$ concentrate (Penicillin
10000 Units/mL, Streptomycin $10 \mathrm{mg} / \mathrm{mL}$ ) (PAA), 2\% LGlutamine $200 \mathrm{mM}, 2 \%$ Sodium Pyruvate $100 \mathrm{mM}$ (PAA), 2\% MEM NEAA $100 \times$ concentrate $($ PAA). Medium was sterilized by filtration.

\section{Competing interests}

The authors declare that they have no competing interests.

\section{Authors' contributions}

PH performed the experiments and wrote the manuscript. $\mathrm{CD}$ coordinated the experiments and wrote the manuscript. MAM performed the experiments and wrote the manuscript.

\section{Acknowledgements}

This study was supported by the German Ministry of Education and Research (Project Code "Ökologie und Pathogenese von SARS"), and the European Commission (contract SSPE-CT-2005-022639).

\section{References}

I. Masters PS: The molecular biology of coronaviruses. Adv Virus Res 2006, 66:193-292.

2. Gorbalenya $A E$, Snijder EJ, Spaan WJ: Severe acute respiratory syndrome coronavirus phylogeny: toward consensus. J Virol 2004, 78:7863-7866.

3. Gonzalez JM, Gomez-Puertas P, Cavanagh D, Gorbalenya AE, Enjuanes $L$ : $A$ comparative sequence analysis to revise the current taxonomy of the family Coronaviridae. Arch Virol 2003, I 48:2207-2235.

4. Hoek L van der, Pyrc K, Jebbink MF, Vermeulen-Oost W, Berkhout RJ, Wolthers KC, Wertheim-van Dillen PM, Kaandorp J, Spaargaren J, Berkhout B: Identification of a new human coronavirus. Nat Med 2004, 10:368-373.

5. Hamre D, Procknow Jj: A new virus isolated from the human respiratory tract. Proc Soc Exp Biol Med 1966, I2 I:190-193.

6. Pyrc $K$, Berkhout $B$, Hoek $L$ van der: Identification of new human coronaviruses. Expert Rev Anti Infect Ther 2007, 5:245-253.

7. Kahn JS: The widening scope of coronaviruses. Curr Opin Pediatr 2006, I 8:42-47.

8. Woo PC, Lau SK, Chu CM, Chan KH, Tsoi HW, Huang Y, Wong BH, Poon RW, Cai J], Luk WK, et al.: Characterization and complete genome sequence of a novel coronavirus, coronavirus HKUI, from patients with pneumonia. J Virol 2005, 79:884-895.

9. Cavanagh D: Coronaviruses in poultry and other birds. Avian Pathol 2005, 34:439-448.

10. Pyrc $K$, Berkhout $B$, Hoek $L$ van der: The novel human coronaviruses NL63 and HKUI. J Virol 2007, 8I:305I-3057.

II. Dijkman R, Jebbink MF, El Idrissi NB, Pyrc K, Muller MA, Kuijpers TW, Zaaijer HL, Hoek L van der: Human coronavirus NL63 and 229E seroconversion in children. J Clin Microbiol 2008, 46:2368-2373.

12. Pyrc $K$, Berkhout $B$, Hoek $L$ van der: Antiviral strategies against human coronaviruses. Infect Disord Drug Targets 2007, 7:59-66.

13. Han TH, Chung JY, Kim SW, Hwang ES: Human CoronavirusNL63 infections in Korean children, 2004-2006. J Clin Virol 2007, 38:27-31.

14. Chiu SS, Chan KH, Chu KW, Kwan SW, Guan Y, Poon LL, Peiris JS: Human coronavirus NL63 infection and other coronavirus infections in children hospitalized with acute respiratory disease in Hong Kong, China. Clin Infect Dis 2005, 40:1721-1729.

15. Bastien N, Robinson JL, Tse A, Lee BE, Hart L, Li Y: Human coronavirus NL-63 infections in children: a I-year study. J Clin Microbiol 2005, 43:4567-4573.

16. Ebihara T, Endo R, Ma X, Ishiguro N, Kikuta H: Detection of human coronavirus NL63 in young children with bronchiolitis. J Med Virol 2005, 75:463-465.

17. Moes E, Vijgen L, Keyaerts E, Zlateva K, Li S, Maes P, Pyrc K, Berkhout $B$, Hoek $L$ van der, Van Ranst M: A novel pancoronavirus RT-PCR assay: frequent detection of human coronavirus NL63 in chil- 
dren hospitalized with respiratory tract infections in Belgium. BMC Infect Dis 2005, 5:6.

18. Pyrc K, Bosch BJ, Berkhout B, Jebbink MF, Dijkman R, Rottier P, Hoek $L$ van der: Inhibition of human coronavirus NL63 infection at early stages of the replication cycle. Antimicrob Agents Chemother 2006, 50:2000-2008.

19. Snijder EJ, Bredenbeek PJ, Dobbe JC, Thiel V, Ziebuhr J, Poon LL, Guan Y, Rozanov M, Spaan WJ, Gorbalenya AE: Unique and conserved features of genome and proteome of SARS-coronavirus, an early split-off from the coronavirus group 2 lineage. J Mol Biol 2003, 331 :991-1004.

20. Scandella E, Eriksson KK, Hertzig T, Drosten C, Chen L, Gui C, Luo $X$, Shen J, Shen X, Siddell SG, et al.: Identification and evaluation of coronavirus replicase inhibitors using a replicon cell line. Adv Exp Med Biol 2006, 58 I:609-6I3.

21. Chen L, Gui C, Luo X, Yang Q, Gunther S, Scandella E, Drosten C, Bai $D, H e X$, Ludewig $B$, et al.: Cinanserin is an inhibitor of the 3C-like proteinase of severe acute respiratory syndrome coronavirus and strongly reduces virus replication in vitro. Virol 2005, 79:7095-7I03.

22. Battegay M, Cooper S, Althage A, Banziger J, Hengartner H, Zinkernagel RM: Quantification of lymphocytic choriomeningitis virus with an immunological focus assay in 24- or 96-well plates. J Virol Methods 1991, 33:191-198.

23. Matrosovich M, Matrosovich T, Garten W, Klenk HD: New low-viscosity overlay medium for viral plaque assays. Virol ] 2006 , 3:63

24. Leyssen P, Charlier N, Paeshuyse J, De Clercq E, Neyts J: Prospects for antiviral therapy. Adv Virus Res 2003, 6 1:5I I-553.

25. Leyssen P, De Clercq E, Neyts J: Molecular strategies to inhibit the replication of RNA viruses. Antiviral Res 2008, 78:9-25.

26. Makino S, Taguchi F, Fujiwara K: Defective interfering particles of mouse hepatitis virus. Virology 1984, 133:9-17.

27. Donaldson EF, Yount B, Sims AC, Burkett S, Pickles RJ, Baric RS: Systematic Assembly of a Full-length Infectious Clone of Human Coronavirus NL63. J Virol 2008, 82(23): I I 948-I I 957.

28. Schildgen O, Jebbink MF, de Vries M, Pyrc K, Dijkman R, Simon A, Muller A, Kupfer B, Hoek $L$ van der: Identification of cell lines permissive for human coronavirus NL63. J Virol Methods 2006, I38:207-210.

29. Fouchier RA, Hartwig NG, Bestebroer TM, Niemeyer B, de Jong JC, Simon $\mathrm{H}$, Osterhaus $\mathrm{AD}$ : A previously undescribed coronavirus associated with respiratory disease in humans. Proc Natl Acad Sci USA 2004, I 1 I:62 I2-6216.

30. Delmas B, Gelfi J, L'Haridon R, Vogel LK, Sjostrom H, Noren O, Laude $\mathrm{H}$ : Aminopeptidase $\mathbf{N}$ is a major receptor for the entero-pathogenic coronavirus TGEV. Nature 1992, 357:4I7-420.

31. Reynolds DJ: Coronavirus replication in the intestinal and respiratory tracts during infection of calves. Ann Rech Vet 1983, 14:445-446.

32. Leung WK, To KF, Chan PK, Chan HL, Wu AK, Lee N, Yuen KY, Sung J]: Enteric involvement of severe acute respiratory syndrome-associated coronavirus infection. Gastroenterology 2003, 125:1011-1017.

33. Cinatl J Jr, Hoever G, Morgenstern B, Preiser W, Vogel JU, Hofmann WK, Bauer G, Michaelis M, Rabenau HF, Doerr HW: Infection of cultured intestinal epithelial cells with severe acute respiratory syndrome coronavirus. Cell Mol Life Sci 2004, 6 I:2 I00-2 I I 2 .

34. Yamashita M, Yamate M, Li GM, lkuta K: Susceptibility of human and rat neural cell lines to infection by SARS-coronavirus. Biochem Biophys Res Commun 2005, 334:79-85.

35. Hofmann H, Pyrc K, Hoek L van der, Geier M, Berkhout B, Pohlmann $S:$ Human coronavirus NL63 employs the severe acute respiratory syndrome coronavirus receptor for cellular entry. Proc Natl Acad Sci USA 2005, 102:7988-7993.

36. Hattermann K, Muller MA, Nitsche A, Wendt S, Donoso Mantke O, Niedrig M: Susceptibility of different eukaryotic cell lines to SARS-coronavirus. Arch Virol 2005, 150:1023-1031.

37. Weingartl HM, Copps J, Drebot MA, Marszal P, Smith G, Gren J, Andova M, Pasick J, Kitching P, Czub M: Susceptibility of pigs and chickens to SARS coronavirus. Emerg Infect Dis 2004, 10:179-184.

38. de Souza Luna LK, Heiser V, Regamey N, Panning M, Drexler JF, Mulangu S, Poon L, Baumgarte S, Haijema B], Kaiser L, Drosten C: Generic detection of coronaviruses and differentiation at the prototype strain level by RT-PCR and non-fluorescent low density microarray. J Clin Microbiol 2007.
Publish with Biomed Central and every scientist can read your work free of charge

"BioMed Central will be the most significant development for disseminating the results of biomedical research in our lifetime. "

Sir Paul Nurse, Cancer Research UK

Your research papers will be:

- available free of charge to the entire biomedical community

- peer reviewed and published immediately upon acceptance

- cited in PubMed and archived on PubMed Central

- yours - you keep the copyright 